\title{
THE AFFECTING FACTORS OF COMMUNITY PARTICIPATION IN RURAL DEVELOPMENT PLANNING: A CASE OF KERTAWANGI VILLAGE OF BANDUNG BARAT DISTRICT
}

\author{
Herdiana D.*, Suwaryo U., Deliarnoor N.A., Rahmatunnisa M. \\ Faculty Of Social and Political Sciences, Universitas Padjadjaran, Indonesia \\ *E-mail: kyberdian@gmail.com
}

\begin{abstract}
This article aims to describe the affecting factors of community participation in rural development planning, low community participation as the problem of the rural development planning in Kertawangi Village. The method used is the descriptive qualitative method, data collection techniques used were observation, interview and documentation. The technique of data analysis is the inductive basis; data reduction, data presentation, data interpretation and conclusion. The result shows that the main affecting factor of community participation in Kertawangi village's development planning is the lack of community knowledge on rural development planning process. Other affecting factors are the lack of openness of the village government apparatus to accept community participation in the process of rural development planning, lack of regulatory support that briefly encourage all community members to participate in rural development planning, as well as there still paternalistic, patriarchy and primordialism that still strongly adopted by the community.
\end{abstract}

\section{KEY WORDS}

Community, participation, planning, villages.

Community participation in rural development planning is raising as an important issues after the implementation of Law Number 6 of 2014 on Villages, the central government not only gives the village government a local-authority to formulate rural development planning based on their potentials and characters, but also changes the approaches of rural planning from centralized planning to participatory planning. This change requires community participation in whole process. The community is placed not only as the object of the development but also as the subject of the development who has the rights to join other stakeholders in formulating the rural development planning based on the mutual interests.

There are at least 3 (three) reasons why rural participatory development planning is important. First, in the conceptual level, the participatory planning development is considered as a new approach (Ray, 2000 and Rietbergen, 2001, in Naku \& Afrane, 2013. p.185) that conceptually criticized the centralized development planning as an old approach that is no longer matches with the recent local-autonomy that implemented widely across the nation. Second, in the practical level, the centralized development planning has experienced many failures (Eko and Krisdyatmiko, 2006), thus raising the idea of replacing the old development planning approach with the new development planning approaches as the answer to overcome those problems. Third, returning the original authority of the village community as a legal community which presenting and involving the community in rural development planning process is a must and a form of government responsibility to encourage community to participate in rural development.

The participatory development planning approach in Indonesian context is implemented through rural deliberative planning forum that bring the community and other stakeholders to jointly identify, compile and decide rural development plans based on mutual understanding and interests. Based on Law Number 6 of 2014 on Villages, the rural deliberative planning forum divide into 2 (two) steps, first Village Consultation Forum (Musyawarah Desa) and Village Development Planning Forum (Musrembang Desa). The aims of the both forum as a means for community to deliver and to channel their aspirations. 
The conceptual purpose of the forums is to join all the stakeholders together equally to make decision of rural planning based on mutual interests. But, in facts it is not in accordance with the conceptual purposes. Rural development planning actually raises the dominant role of village government and directly resulted declining of community participation. The village development program is trapped into a ceremonial forum which not only failed to create a dialogical participatory forum, but also failed to bring aspiration of the community demands into rural planning program (Karyana, 2011: 140-156), the accommodation of aspirations that becomes rural policy through Village Consultation Forum (Musyawarah Desa) and Village Development Planning Forum (Musrembang Desa) is still minimal (Putri, et al ..2015: 1-11).

Another problem araising is lack of community understanding for the process of the rural development planning, the community did not know what should to do during the rural development planning process, consequently during the Village Consultation Forum (Musyawarah Desa) and Village Development Planning Forum (Musrembang Desa), village government dominates the whole process, the village development policy produced did not reflect the needs and demands of the community, it more tends to impose the interests of the village government.

In line with the above problems, the empirical practice of rural development planning in Kertawangi village shows similar symptoms, such as low community participation in rural development planning that indicated by many people who do not know the process of village development planning, the present of the community in both Village Consultation Forum (Musyawarah Desa) and Village Development Planning Forum (Musrembang Desa) does not represent all elements of the community. Last but not least, during Village Consultation Forum (Musyawarah Desa) and Village Development Planning Forum (Musrembang Desa), the community member who attended was passive and did not understand what role/aspiration should be given, so that the community did not provide their contribution to rural development planning properly.

Based on the problems above, it is necessary to conduct a study that analyze the factors that influence community participation in the rural development planning process, therefore this article aims to further both describe and analyze the affecting factors of community participation in Kertawangi Village's development planning.

\section{METHODS OF THE RESEACH}

To reveal more deeply about the affecting factors of rural development in Kertawangi village's development planning uses descriptive analysis methods. As disclosed by Sugiyono (2010: 8) which states that qualitative research methods are often referred to as naturalistic research methods because the research is carried out in natural conditions, so that the existing reality can be disclosed as what it is without being influenced by the existence of the researchers that could possible to reduce or influence the data.

In connection with the data revealed in this study is a narrative description data from various informants as well as from other data sources, this is in line with what is expressed by Garna (1999: 32) which states that a qualitative approach is oriented to understanding various symptoms that do not always require quantification, so that the results of using a qualitative approach will produce a description of the existing problems.

Sources of data in this study are informants and documentation from various sources, where there are two types of data sources, namely primary data sources and secondary data sources (Riduan, 2007: 24). Both primary data sources and secondary data sources are sourced from relevant stakeholders involved in rural development planning, focusing on community participation.

The research instrument is a tool to collect data in research. In this study the research instrument is the researcher himself (human instrument). Data collection techniques conducted in this study consists of observation, interviews (in-depth interviews) and documentation. Data analysis in this study is the activity of compiling data, namely compiling and sorting data into a particular category so that it can be interpreted and given the 
meaning, which is done through 3 (three) stages as revealed by Creswell (1994: 153) namely data reduction, data presentation and conclusion or verification.

\section{RESULTS AND DISCUSSION}

Participatory planning is the planning that involves the community in achieving its goals, in line with the above understanding Wicaksono and Sugiarto (Wijaya, 2003: 16) says that participatory planning is an effort carried out by the community with the aim of solving problems based on the needs and ability of the community itself.

From those understanding, it is clear that participatory planning places the community on an important position, the community is a terminology used as a source of what problems must be solved and also as a subject to determine policy on the problem based on community interests. Furthermore, participatory planning is not only present the community physically, but also should able to present community as a capital that should give contributions, this is in line with the understanding from Samsura (2003: 2) that at least there are 4 (four) point of the planning to be called into participatory planning, the criteria as follows:

- There must be the involvement of all actors or stakeholders;

- There must be an effort to realize a community institution that has a legitimate nature;

- There must be a deliberation process or consultation process which will result in a collective agreement;

- There must be an effort to empower the community through learning activities as a manifestation of the democratization process.

From the above understanding, it is clear that presenting the community as a form of participation in development planning is a must and should be supported by all stakeholders in order to make the development meet its goals. Related to the participatory planning, community role main position who has the authority not only to determine their needed, but also to make a decision by own to meet their needed.

Participation is an involvement of community in the development both in the planning process and in the implementation process (Adisasmita, 2006:p.38). Meanwhile Pusic (Adi, 2001: 206-207) states that developments plan without participation or community involvement will become planning on paper. Therefore participation has reciprocity between two actors or more, participation is a feed-forward information and feedback information (Carter in Arimbi, 1993:1).

From the above understanding, it can be understood that participation is a process that intertwined in a two-way and reciprocal, related to village development planning, two-way relationship can be interpreted as a reciprocal relationship between the village government and the community.

There are many aspects affecting community participation, Slamets (Nurbaiti and Bambang, 2017: 224-228) says that community participation is influenced by knowledge and expertise, community work, education level and illiteracy, gender, belief in certain cultures. In line with the understanding above Angell (Ishak, et al., 2016: 70-71) states that participation that grows in society is influenced by awareness factors, factors of age, sex, education, occupation, length of stay, government support and equipment / facilities support. Meanwhile Kessa (2015: 14) says that factors affecting community participation consist of psychological factors, economic factors and cultural factors. In this article the factors that become the focus of the study are regulatory factors, community factors, village government factors and culture factors. The explanations of the affecting factors as follows:

Conceptually, the role of the community in rural development is both as the object as well as the subject of rural development. In a participatory planning that implemented in Kertawangi village should also put the village government and the community into the same position, both have the same rights in finding, formulating and identifying problems of rural development. But in facts, it is not in line with the conceptual framework. One of the reason is because of the Law Number 6 of 2014 on Villages does not accommodate the conceptual understanding above. 
The conceptual of equal rights between village government and the community in rural development planning translated differently in The Law Number 6 of 2014 on Villages, the community in the Law Number 6 of 2014 on Villages is positioned as a "complement" and not a subject that has the same rights as the village government, this is stated in Article 80 paragraph 1 as "Village Development Planning is organized by including the village community".

The terminology of "including" in practice is defined as the authority of development planning to be entirely in the hands of the village government, while the community is the "included" part of the village development planning. The village government has power over rural development planning where the community is an element in it.

This understanding ultimately gives the assumption that rural development is the desire of the village government along with all its interests and the position of the community is only used as a justification for the policy made by the village government, the community not placed as an object in rural planning development.

Another thing that has become a weakness in Law Number 6 of 2014 on Villages is that there are restrictions on the community who have the right to attend and participate in the village development planning forum, the limitation of the presence of the community has directly limited the community member to participate and to be involved in the rural development planning, ideally the right for each member of the community can be presented in the rural development planning forum and being participated according to their respective abilities.

Rural participatory development planning requires community participation to succeed. The results of the study show that there are many inhibiting factors originating from the community, these factors can be explained as follows:

Kertawangi Village just like other villages in West Bandung Regency that still faced with a low level of community education, some of the community are still elementary school graduates, even among those who are still illiterate. Even so, the majority of people are high school graduates.

Associated with community participation in rural development planning, education level influences the way people articulate issues or problems of rural development that are limited to basic issues such as infrastructure issues, poverty alleviation and job creation. Issues such as empowering women and disabilities people, developing human resources are rarely addressed. This is inseparable from the mindset of the people who still interpret rural development to physical development. Whereas at the level of the structure of rural development planning, both physical development and non-physical development are equally important and can contribute to the success of the rural development.

Livelihood or type of community work influences community participation in rural development planning. People who have works or jobs outside Kertawangi village and bounded to work time from morning to evening have a tendency not to be actively involved in the rural development planning; this is because the community members should take time off from their work if they want to be actively involved in rural development planning. The impact of the community's work is that in the implementation of development planning forums, both Village Consultation Forum (Musyawarah Desa) and Village Development Planning Forum (Musrembang Desa), those who attend the forums are working in Kertawangi Village or people who work outside Kertawangi Village but have flexible time. The facts above show that rural development planning should be carried out flexibly in keeping with the availability of community time.

The poverty in Kertawangi village affects people's participation in rural development planning, the poor are more interested to be involved in the implementation of rural development than being participated in rural development planning, although in the Law Number 6 of 2014 on Villages explicitly to accommodate the poor and women, some of poor community still prefer participating in the implementation of rural development.

They argues that development planning is a process of rural development which does not necessarily mean that their aspirations will be accommodated and the benefits of their involvement would not have a direct impact, whereas in the implementation of development, 
the poor will be involved such as being builders in the construction of rural roads and will receive rewards from their participation in the implementation of development. There are many members of the community who have the desire to participate by way of conveying the problems or aspirations that have existed, but they have no way of what should they do, most of community member do not know how they can channel their aspirations, especially regarding issues related to rural development planning. The community claimed that the local government (both provincial government and district government) did not provide socialization or training regarding community involvement in rural development planning, so they did not know to whom their aspirations were conveyed.

The statement was acknowledged by the village government which stated that the village government and the district government did not carry out training activities in the framework of community empowerment related to community participation in rural development planning, even though the village government stated the commitment to conduct socialization and training aimed at increasing public understanding of the rural development issues and encourage community participation to be involved in rural development planning.

It is undeniable that there are some people who have apathy and do not care about rural development planning that is being implemented, those people basically do not have any more concern for rural development. One of the reasons why some of the community are not interested in being involved in rural development planning is because in the past they were actively involved in development planning, but they felt disappointed because their aspirations and needed were not accommodated. This problem has become a concern for the village government to build trust and help the apathetic community to change their mind and attitude to then jointly participate in rural development planning by showing them the output of rural development planning that truly accommodate the interests of the community.

Village government plays an important role in rural development planning; this is based on Law No. 6/2014 on villages which stipulates that the village government is an organization at the village level that is given the authority to make rural development planning.

The authority given is demanding the village government to be able to carry out rural development planning in participatory approaches by involving the community. However, the implementation of rural development planning in Kertawangi Village is not in line with these objectives. The village government has not fully presented the community as part of rural development planning which has the same rights to formulate rural development planning. The above problems are caused by several factors as follows:

Kertawangi village government is still stuck with the old paradigm where the village government is part of the local government (Subdistrict Government) which should submit and obey to the vertical institutions above, including obey the rural programs that comes from local government (Subdistrict Government). The enactment of Law No. 6/2014 on Villages authorizes village government to plan rural development independently and structurally is no longer as a vertical part of local government (Subdistrict Government).

The old paradigm is still inherent in the government of Kertawangi village, the village apparatus defines rural development planning as part of the task of the village government vertically, development planning is carried out on the granting of authority from the local government (Subdistrict Government). In the process, all forms of rural development planning activities and program should be in accordance with the wishes and guidelines of the local government (Subdistrict Government).

This has bad implications for the village government which prioritizes and accommodates local government interests first compared to the community. The village government forgets the role of the community in the participatory development planning which community has the rights to get involved equally and determine the policy of rural development planning.

There needs to be an effort to change the mindset of the village government to accept a new paradigm in rural development planning in which the village government should accept that society is presented not only as a subject, but also as an object of rural development 
planning who has the rights to be involved in the entire process of rural development planning.

The lack capacity of the village government apparatus in rural development planning is evidenced by the limited number of village apparatus, amounting to 12 people and the majority of them are high school graduates (Kertawangi Office, 2018). In the context of rural development planning, not all village officials take part in the rural development planning process.

This has implications for the quality of the process of rural development planning as expected, for example where in the stages of rural development planning such as the process of identifying problems in the community is carried out formally by the village apparatus. In practice the village apparatus does not know what is called a problem, how the problem is identified / formulated and what methods are used to determine the problem. Their misunderstanding is due to the level of education and also not all village apparatus take part in training of rural development planning.

Another thing as the implication of the limited capacity of the village government apparatus is the lack of understanding regarding community participation and what benefits will be gained if the community is widely involved in the process of rural development planning process.

The mindset of the Kertawangi village apparatus is still limited to understanding the presence of the community as the subject of development in which many rural development problems come from the community such as high levels of poverty, low levels of public health and so on. Understanding the village apparatus has not yet arrived at a position that places the community as a civilian capital that has the rights and able to encourage the achievement of success in rural development planning.

Other factors that influence community participation in rural development planning are the lack of common thought and willingness of the village government, the village head, village apparatus and village consultative body (BPD) have no same thought in making the rural development planning as a forum that not only brings village government together with the community but also provides opportunity to the community to voice aspirations, identify problems and participate in deciding rural development planning policy.

There is still an ego from the Kertawangi village government that development planning is the authority of the village government and makes the community only as a source of information on the problems of existing rural development. The community is placed in the position as the object of rural development to explore, identify and formulate problems of rural development, not placed the community as subjects who have the right to formulate and determine village development policies, the community has not been able to be placed as an actor in rural development that determines and drives the direction of rural development.

A commitment from the village government is needed to realize the community as a civilian capital that acts as a subject as well as an object in rural development. This will be built through the consistency of the village government opening up and continuing to encourage the community to always participate in rural development planning and make rural development a shared responsibility.

One of the tasks of the village government is community empowerment, including empowerment in the rural development planning process, so that the community has the responsibility to be involved in it, but in Kertawangi village there is few community empowerment programs from the village government specifically aimed at encouraging community to participate in rural development planning. The implication resulted the community did not knowing either the process of channeling community aspirations or the process of community participation in rural development planning.

Some community member in Kertawangi village do not know in what way and to whom and what process to channel their aspirations, this is because there is no socialization to the community about the process. Then also for the community member who participated in the rural development planning that was carried out also did not know the stages of the rural development planning and what role should be given, it is due to the lack of socialization and training activities regarding the process and techniques for the rural development planning. 
The rights of the community to participate in rural development planning should be followed by the willingness of the village government to provide access for the community to rural development planning documents. This is a needed, so that the community understands the substance inside of the rural development planning documents and will contributes in determining the material or substance of the rural development planning documents.

But the practice in Kertawangi village, community have difficulty accessing rural development planning documents, Kertawangi village government does not fully provide the rural development planning documents that are being implemented, even though the village government opens documents to the community, only certain member of community that have access to rural development planning documents.

Another thing in the difficulty of community accessibility to rural development planning documents is that in the process of development planning forums, both Village Consultation Forum (Musyawarah Desa) and Village Development Planning Forum (Musrembang Desa), rural development planning documents is given at the beginning of the forum, not in the previous day, so that in the ongoing forum community concentration was divided into two, first listening to the material presented by the village government and the second reading the rural development planning documents provided.

This condition of course not ideal for rural development planning based on participatory approaches where the community before the development planning forum both Village Consultation Forum (Musyawarah Desa) and Village Development Planning Forum (Musrembang Desa) should be given the rural planning documents.

Culture according to Johnston et al (in Stephenson, 2008: 129) is a dynamic process involves the community that can be based on certain social processes (Thrift and Whatmore in Stephenson, 2008: 129), in relation to rural development planning, culture will not only form the characteristics and the output of the development, but also will determine the pattern of community participation.

In the process of rural development planning, cultural constraints are often far more important than the values of individual interests. (Mill in Guiso et al., 2006, p. 26), this understanding is in line with the existing conditions in Kertawangi Village where culture is also becoming influencing factors in rural development planning, including contributing to community participation. Although culture has a more positive impact on rural development planning, it is also has a negative impact, the culture that is adopted by the people in Kertawangi village and become affecting factors of community in rural development planning can explain as follows:

Kertawangi as a village with majority of Sundanese ethnicity puts the village head or "kuwu" as a respected leader both in the social context and in the village administration context, this position placed head village superior over the community. So that, in process of rural development planning if there is a critical attitude from the member of the community or even contradicts toughts towards the village head, it can be interpreted as an attitude of disrespect of the village head, so it is not surprising that in Village Consultation Forum (Musyawarah Desa) and Village Development Planning Forum (Musrembang Desa) the community were passive and just approving what was conveyed by the village head, this is due to reluctance, respect for the leader and the older people is a principle in the life of the community.

Those manner is inseparable from the paternalistic culture that is still closely adopted by the community in Kertawangi Village, where the village head as a leader is not only central to the decision-making process, but also regarded as omniscient and omnipotent (Erlangga, et al. P: 177).

The paternalistic also influences the identification and formulation of rural development issues centered on the interests of the village head where the village head places his position to determine and manage what development planning issues is suitable for development planning. Whereas in the context of rural development planning, one of the principle of community participation is the involving of the community and shown by involving community in the process of formulating issues and identifying problems (Adi, 2007: 27). The 
community has the rights to determine which issues are eligible to be identified /assessed and made a decision into development planning policy.

The paternalistic in Kertawangi village becomes dilemma for community whose lives are still communalistic and homogeneous, on the one hand the paternalistic can become capital for village heads who have the capability as catalysts for accelerating rural development to ask the community together to advance their village through better development, but in practice this paternalistic is used by the village head for personal matters and interests by dominating development issues and problems, so that the development planning is more reflective of the wishes and interests of the village head rather than reflecting the aspirations and demands of the community.

Other culture that is still adopted by the community and has negative implications for community participation in rural development planning is a patriarchal that considers men to be superior compared to women (Sakina \& Siti A.2017: 72). This proof by only a few women in Kertawangi village who became community leaders or person who had influence (Sesepuh Desa). The consequences of few female leaders in Kertawangi Village resulted a lack of representation of women who attending Village Consultation Forum (Musyawarah Desa) and Village Development Planning Forum (Musrembang Desa), the forum is dominated by the men.

In the process of Village Consultation Forum (Musyawarah Desa) and Village Development Planning Forum (Musrembang Desa) the role of women leaders who attended those forum did not contribute too much both in the delivery/bargaining the ideas and influencing power in decision making of rural planning policy, they presents was passive, some of them only responded to what was conveyed by village heads and village government apparatus without making complain.

On the one hand, women's representation is very important in rural development planning because both the quantity of the large women population in village and the many existing problems that require the intervention of women. Even the patriarchal still stongly adopted by the community in Kertawangi Village and cannot be eliminated in a short time, it is needed to have a joint commitment among all stakeholders to provide equal rights and obligations for both men and women to be equally responsible and involved in rural development planning.

Other culture affecting community participation in Kertawangi village's development planning is primordialism in which the attitude of a person or community determined by the bonds they have from birth such as race and customs (Maryati, et al: 2014: 17). The primordialism in the rural development planning is shown by less accommodating the issues/problems and the presence of newcomers (outsiders/ or people who newly live in the village) in the village development planning process. This implies the attitude of apathetic from the newcomers towards rural development planning because from the beginning they feel that their aspirations are not accommodated and not directly involved to attending the rural development planning forums, so that the sense of belonging and the sense the of responsibility to participate in development planning among newcomers is still minimal.

\section{CONCLUSION}

This article can be concludes that there are 4 (four) affecting factors of community participation in Kertawangi Village's development planning, namely: First, the regulatory factors which the community present in rural development planning forum (Musyawarah Desa and Musrembang Desa) is limited, only few of them is allowed to attend the forum. Second, the community's internal factors which there are still many people who have a low education, as well as lack of knowledge on rural development planning process. Third, the village government factors, which the apparatus has not fully opened up to community participation in rural development planning. Fourth, cultural factors which the paternalistic, patriarchy and primordialsm places the community inferior to the village government. 


\section{REFERENCES}

1. Adi, Isbandi Rukminto. (2001). Pemberdayaan, Pengembangan Masyarakat dan Intervensi Komunitas. Jakarta: Lembaga Penelitian FE-UI.

2. (2007). Perencanaan Partisipatoris Berbasis Aset Komunitas: Dari Pemikiran Menuju Penerapan. Depok: FISIP UI Press.

3. Adisasmita, Raharjo. (2006). Pembangunan Pedesaan dan Perkotaan. Yogyakarta: Graha IImu.

4. Arimbi. 1993. Peran Serta Masyarakat dalam Pengelolaan Lingkungan. Jakarta: WALHI.

5. Creswell, John W. 1994. Research Design: Qualitative and Quantitative Approaches; Sage Publication. Sixth Edition. New York: Haughton Miffin Company.

6. Eko, Sutoro \& Krisdyatmiko. (2006). Kaya Proyek Miskin Kebijakan. Yogyakarta: IRE Yogyakarta.

7. Erlangga, Farera dkk. (2013). Pengaruh Gaya Kepemimpinan Paternalistik Terhadap Motivasi. Jurnal Humanis. 12(2). 174-195.

8. Ishak, Fistarisma, Rostin dan Ambo Wonua Nusantara. 2016. Analisis Partisipasi Masyarakat Dalam Menunjang Pembangunan Desa Di Kecamatan Tongauna Kabupaten Konawe. Jurnal Ekonomi (Je) 1(1).

9. Garna, Judistira K. (1999). Filsafat dan Etika Pemerintahan. Bandung: Primaco Akademika.

10. Guiso, L., Sapienza, P., \& Zingales, L. (2006). Does Culture Affect Economic Outcomes?. Journal of Economic Perspectives, 20(2), 23-48.

11. Kantor Desa Kertawangi. Profil Desa Kertawangi Tahun 2018. Bandung: Kantor Desa Kertawangi.

12. Karyana, Ayi. (2011). Pengorganisasian Perencanaan Desa: Kajian Di Desa Kalongsawah Kecamatan Jasinga Kabupaten Bogor. Jurnal Organisasi dan Manajemen. 7(2). 140-156.

13. Kessa, Wahyuddin. 2015. Perencanaan Pembangunan Desa. Jakarta: Kementerian Desa, Pembangunan Daerah Tertinggal dan Transmigrasi Republik Indonesia.

14. Naku, Daniel Wandera Clief \& Sam Afrane. (2013). Local Community Development and the Participatory Planning Approach: A Review of Theory and Practice. Journal of Social Sciences 5(5): 185-191.

15. Nurbaiti, Siti Robiah \& Bambang Aziz Nur. (2017). Faktor-Faktor yang Mempengaruhi Partisipasi Masyarakat dalam Pelaksanaan Program Corporate Social Responsibility (CSR). Proceeding Biology Education Conference. 14(1). 224-228. ??

16. Maryati, Kun dkk. 2014. Sosiologi. Solo: PT. Tiga Serangkai Pustaka Mandiri.

17. Putri, Rizki Ayuning Eko, dkk. (2015). Studi Tentang Evaluasi Pelaksanaan Musyawarah Perencanaan Pembangunan (Musrenbang) Di Tingkat Desa Di Kabupaten Sigi Tahun 2014-2015. eJurnal Katalogis. 3(11). 1-11.

18. Riduwan dan Sunarto. 2007. Pengantar Statistika, Untuk Penelitian Pendidikan, Sosial, Ekonomi, Komunikasi dan Bisnis. Bandung: Alfabeta.

19. Sakina, Ade Irma \& Dessi Hasanah Siti A. (2017). Menyoroti Budaya Patriarki. Jurnal Social Work. 7(1). 71-80.

20. Samsura, DA Adriansyah. (2003). Parcipatory Planning, Good Governance dan Civil Society. Makalah: Ragam Warta-Parcipatory Planning.

21. Sugiyono. (2010). Metode Penelitian Kuantitatif, Kualitatif dan R \& D. Bandung: CV. Alfabeta.

22. Stephenson, J. (2008). The Cultural Values Model: An Integrated Approach To Values In Landscapes. Landscape And Urban Planning, 84(2), 127-139.

23. Undang-Undang Republik Indonesia Nomor 6 Tahun 2014 Tentang Desa.

24. Wijaya, Rina. (2001). Forum Pengambilan Keputusan dalam Proses Perencanaan Pembangunan di Era Otonomi Daerah (Studi Kasus Di Kelurahan Jebres Kecamatan Jebres Kota Surakaarta). Tesis, Magister Perencanaan Kota dan Daerah. Yogyakarta: Universitas Gadjah Mada. 